\title{
TAXONOMIC AND NOMENCLATURAL NOTES ON HIERACIUM TOMOSENSE (ASTERACEAE), A NEGLECTED CARPATHIAN ENDEMIC
}

\author{
ZBIGNIEW SZELĄG
}

\begin{abstract}
Hieracium tomosense Simk., a mountain forest species known to date only from the Piatra Mare Mts in the Southern Carpathians, Romania, has been found in other parts of the Southern and Eastern Carpathians. This hybridogenous species of the morphological formula $H$. transylvanicum $>H$. murorum was incorrectly included by Zahn and Nyárády into $H$. transylvanicum Heuff. as a variety, thus sending $H$. tomosense into oblivion. A distribution map of $H$. tomosense is presented and its relation to $H$. praecurrens is discussed. The name $H$. tomosense is lectotypified by a specimen stored at the Hungarian Natural History Museum in Budapest (BP).
\end{abstract}

Key words: Asteraceae, Carpathians, distribution map, Hieracium tomosense, typification

Zbigniew Szelag, Institute of Botany, Jagiellonian University, Kopernika 31, 31-501 Kraków, Poland; e-mail: azszelag@wp.pl

Hieracium transylvanicum Heuff. occurs in the Southern and Eastern Carpathians (Romania and Ukraine), and in the central and western parts of the Balkan Peninsula (from Bulgaria to Slovenia), reaching Carinthia in SE Austria (Bräutigam 1992). This diploid species (Yurukova-Grancharova et al. 2006; Szeląg et al. 2007; Ilnicki et al. 2010) frequently forms hybrids with $H$. murorum s.l., named $H$. praecurrens s.l. Zahn (1935) distinguished within $H$. praecurrens s.1. 26 taxa at subspecies rank, which became subject of my studies. Examination of living plants, both in the wild and in the garden, the majority of the alleged subspecies being derived from their type localities, as well as comparison of the corresponding original specimens, led me to conclude that many of them are conspecific with $H$. praecurrens Vuk. and do not merit taxonomic recognition. One of them, however, does deserve attention. Hieracium tomosense Simk. (Fig. 1) is a hybridogenous species described from the Piatra Mare Mts (Nagyköhavas in Hungarian) in the Southern Carpathians in Romania (Simonkai 1886). Hieracium tomosense has ovate, mostly rounded at the apex, rich green, glossy basal leaves (Fig. 2) and a compact synflorescence composed of a lesser number of smaller capitula than in $H$. praecurrens s.l., which make the former closer to $H$ transylvanicum. Probably that was why Zahn (1935) and later also Nyárády (1965) regarded H. tomosense as a variety of $H$. transylvanicum, thus sending $H$. tomosense into oblivion. Nevertheless, I repeatedly found typical $H$. tomosense in various parts of the Carpathians (Fig. 3). It was also reported by Wołoszczak (1890) from the Chornohora Mts (Fig. 3: dot 2), but I could not find his herbarium specimens. I have not found $H$. tomosense outside the Carpathians so far.

Karyological studies suggest that H. tomosense is a tetraploid (Ilnicki \& Szeląg 2011), while H. praecurrens s.1. is a triploid (Chrtek et al. 2004; Mráz \& Szeląg 2004). These results do not seem based on a sample large enough to be deemed conclusive, however.

Identification of $H$. tomosense was facilitated by finding original material in the Hungarian Natural History Museum in Budapest (BP), out of which I chose a lectotype of the name.

Hieracium tomosense Simk.

Figs 1-3

Enum. Fl. Transsilv.: 374. 1886.

TYPE LOCALITY: 'Brassó mellett az Obunuj patak felsőbb sziklás részein. Havasutján a Köhavas alatt 


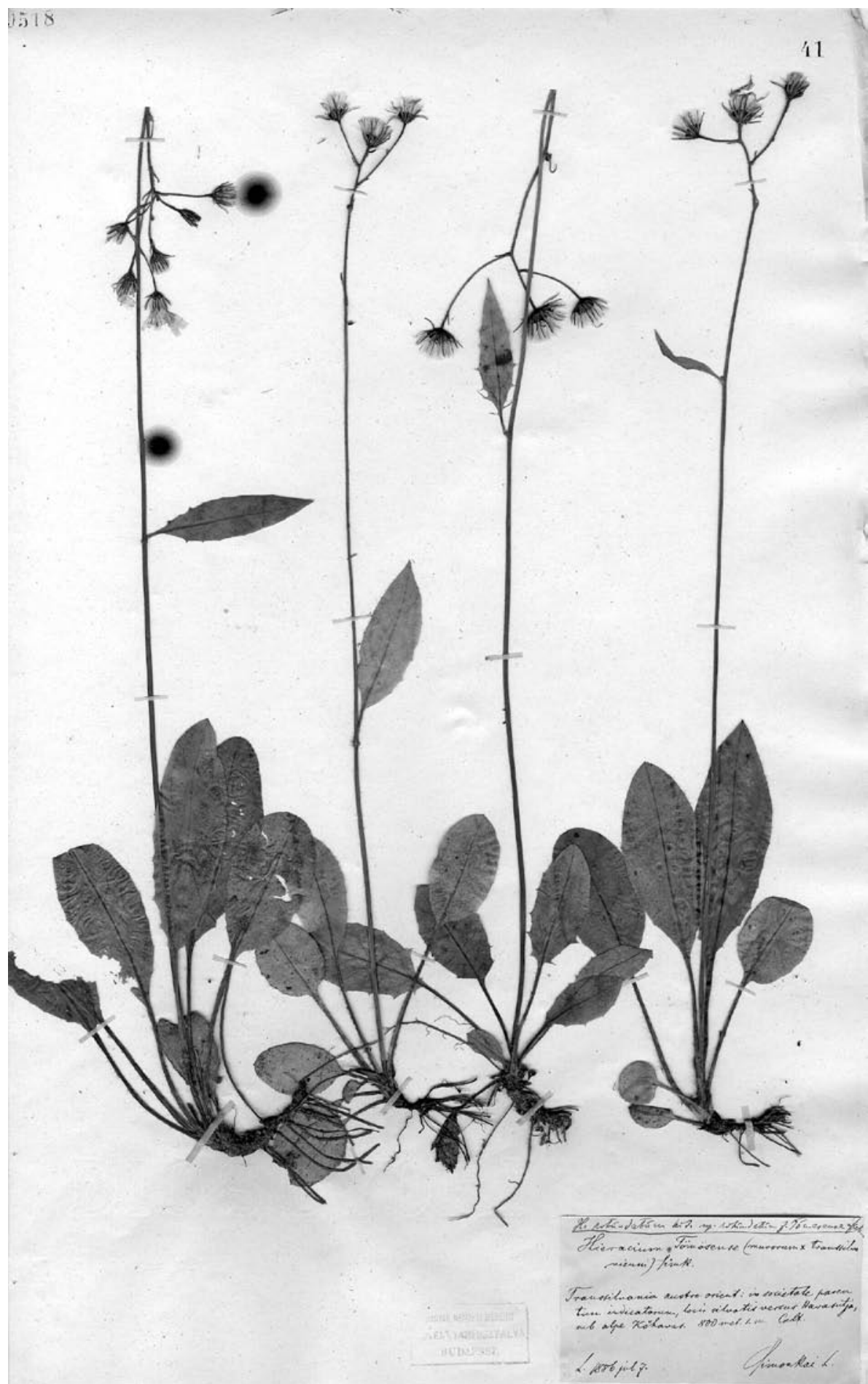

Fig. 1. Lectotype of Hieracium tomosense Simk. 


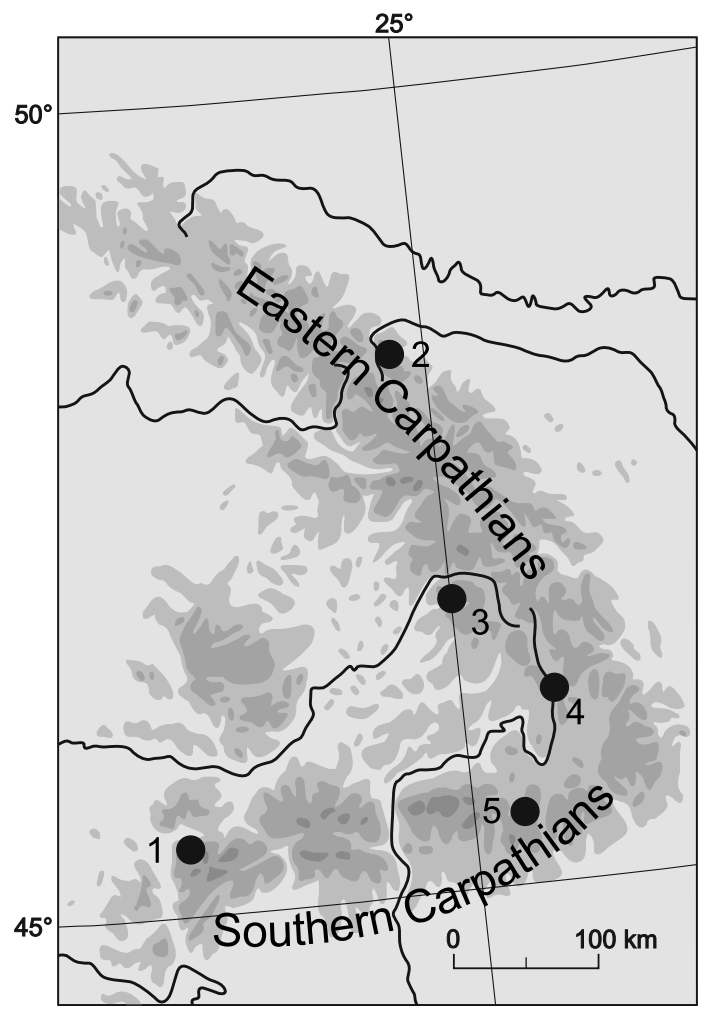

Fig. 2. Distribution of Hieracium tomosense Simk. 1 - Retezat Mts, 2 - Chornohora Mts, 3 - Gurghiului Mts, 4 - Hargita Mts, 5 - Piatra Mare Mts.
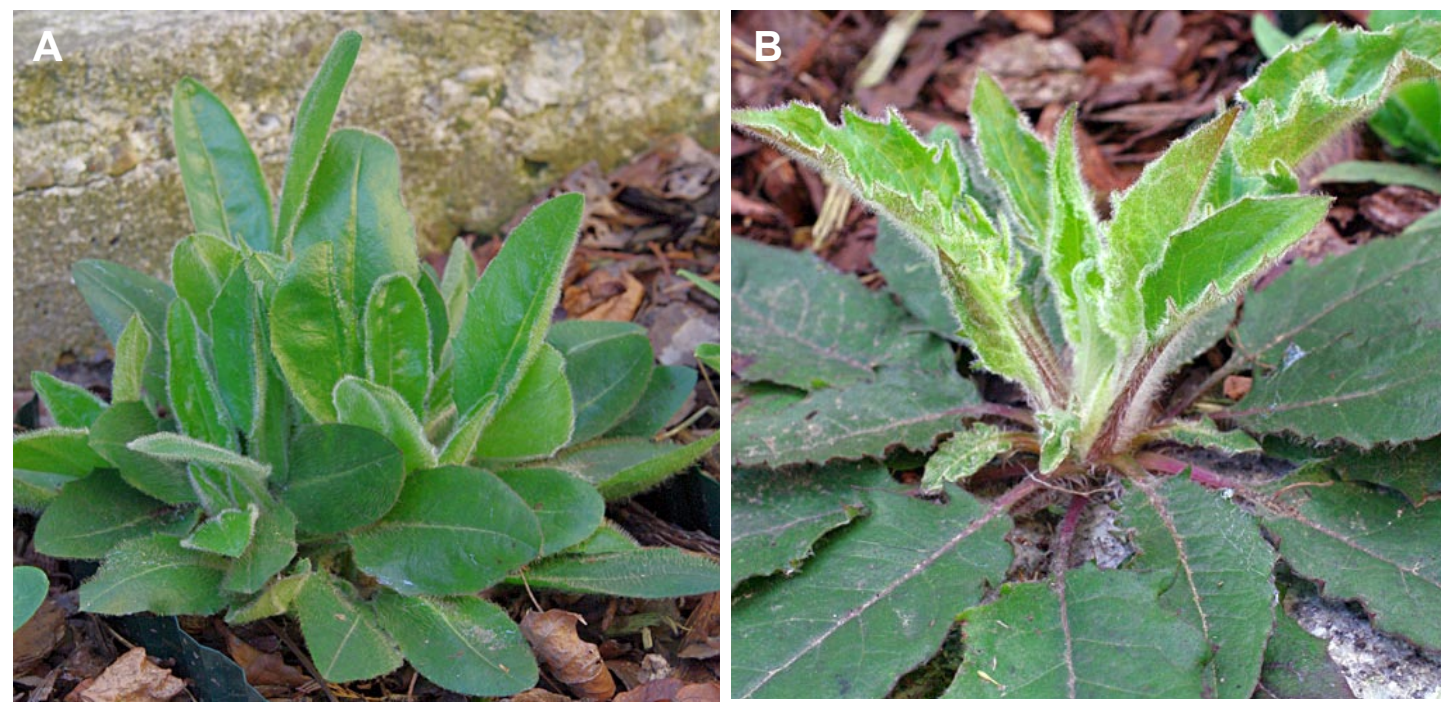

800-900 mét. magasságban bőven' - LECTOTYPE (designated here): $H$. rotundatum Kit. ssp. rotundatum $f$. Tömösense Zahn [manu K. H. Zahn]. Hieracium Tömösense (murorum $\times$ transsilvanicum) Simk. Transsilvania austro-orient: in societate parentum indicatorum, locis silvatis versus Havasutjan sub alpe Köhavas. 800 met. s. m. Cult. 1886 jul. 7. Simonkai L. [original label in Simonkai's handwriting] (BP 9518) - ISOLECTOTYPE: BP s.n. [with attached label in Zahn's handwriting: 'Nicht transsilvanicum $\mathrm{x}$ silvaticum. H. pleiophyllum Vukot. ssp. Tömösense (Simk.) Zahn'].

NotE. The upper Tömösch River valley (Timiş in Romanian) in the Piatra Mare Mts is an area of a very rich flora, visited frequently by 19thcentury botanists. On 12 August 1853, Ferdinand Schur collected there ("Auf Nagelflur im Walde am Tömösch auf lockerer Dammerde') specimens, based on which he described $H$. pseudomurorum Schur 'media inter H. murorum et lasiophyllum' (Schur 1859: 209). This taxon was not included into Enumeratio Plantarum Transsilvaniae (Schur 1866), however. Simonkai (1886: 374) mentioned $H$. pseudomurorum as a synonym of $H$. transylvanicum, while Zahn (1935: 425, 445) included $H$. pseudomurorum into $H$. murorum s.l. As I have not seen the original material of $H$. pseudomurorum collected by Schur, I cannot decide its taxonomical placement.

Fig. 3. Basal leaves of garden-cultivated plants: A - Hieracium tomosense Simk., B - H. praecurrens Vuk. 
LOCALITIES OF HIERACIUM TOMOSENSE: 1 - Romania, Southern Carpathians, Retezat Mts, Zlătuia valley, $1620 \mathrm{~m}$ a.s.1., Picea abies forest on granite. 2 Ukraine, Eastern Carpathians, Chornohora Mts, Mt. Jaworowy near Mikuliczyn (Wołoszczak 1890). 3 Romania, Eastern Carpathians, Gurghiului Mts, Sălard valley, $830 \mathrm{~m}$ a.s.l., Picea abies forest on sandstone. 4 - Romania, Eastern Carpathians, Hargita Mts, Mt. Piatra Şoimilor in Băile Tuşnad, 720 m a.s.l., Fagus sylvatica forest on schist. 5 - Romania, Southern Carpathians, Piatra Mare Mts. (locus classicus).

ACKNOWLEDGEMENTS: I am grateful to Dr. Konstantin Dobolyi and Dr. Lajos Somlyay for their kindness and help during my visit to BP and for photographing Simonkai's specimens, and to the anonymous reviewers for critically reading the manuscript.

\section{REFERENCES}

BrÄUtigam S. 1992. Hieracium L. In: H. MEuSEL \& E. J. JÄGER (eds), Vergleichende Chorologie der zentraleuropäischen Flora. 3: 325-333. Gustav Fischer, Jena.

Chrtek J., Mráz P. \& Severa M. 2004. Chromosome numbers in selected species of Hieracium s.str. (Hieracium subgen. Hieracium) in the Western Carpathians. Preslia 76: 119-139.

ILNICKI T. \& SzelĄG Z. 2011. Chromosome numbers in Hieracium and Pilosella (Asteraceae) from Central and Southeastern Europe. Acta Biol. Cracov. Ser. Bot. 53(1): 102-110.

Ilnicki T., Hasterok R. \& Szeląg Z. 2010. Cytogenetic analysis of Hieracium transylvanicum (Asteraceae). Caryologia 63: 192-196.

MrÁZ P. \& SZEląG Z. 2004. Chromosome numbers and reproductive systems in selected species of the genera Hieracium L. and Pilosella Hill (Asteraceae) from Romania. Ann. Bot. Fenn. 41: 405-414.

NYÁRÁdY E. I. 1965. Hieracium L. In: E. I. NYÁRÁDY (ed.), Flora Republicii Populare Romîne. 10: 214-746, Editura Academiei Republicii Populare Romîne, Bucureşti.

SCHUR F. 1859. Botanische Rundreise durch Siebenbürgen. Verh. Mitth. Siebenbürg. Vereins Naturwiss. Hermannstadt 10: $185-212$.

SCHUR J. F. 1866. Enumeratio plantarum Transsilaniae, exhibens: stirpes phanerogamas sponte crescentes atque frequentius cultas, cryptogamas vasulares, Characeas, etiam muscos hepaticasque. G. Braumüller, Vindobonae.

SimONKAI L. 1886. Enumeratio Florae Transsilvanicae Vesculosae Critica. Magyar Természettudományi Társulat, Budapest.

SzeląG Z., Ilnicki T., Niketić M. \& Tomović G. 2007. Diploid chromosome numbers in five Hieracium species from Serbia and Montenegro. Acta Biol. Cracov. Ser. Bot. 49(1): 119-121.

YuRUKOVA-GRANCHAROVA P., ROBEVA-DAVIDOVA P. \& VLADIMIROV V. 2006. On the embryology and mode of reproduction of selected diploid species of Hieracium s.l. (Asteraceae) from Bulgaria. Flora 201: 668-675.

WoŁoszczaK E. 1890. Trzeci przyczynek do flory Pokucia. Spraw. Komis. Fizjogr. 25: 51-77.

ZAHN K. H. 1935. Hieracium. In: P. GRAEBNER FIL. (ed.), Synopsis der mitteleuropäischen Flora 12(2): 1-790. Borntraeger, Leipzig. 